\title{
Vice-Chancellors Influence on Academic Staff Intentions to Use Learning Management Systems (LMS) For Teaching and Learning
}

\author{
J. Macharia \& E. Nyakwende
}

\begin{abstract}
Universities world over are increasingly deploying learning management systems to enhance the quality of teaching and learning as well as to increase access to higher education. However, since technology rejection is common, the future of universities depends on their instructor's capacity to adopt and diffuse such technologies to meet the intricate needs of the academic masses. Consequently, the purpose of this paper is to investigate the factors that inhibit or accelerate the adoption and diffusion of Learning Management System (LMS) by academic staff for teaching and learning activities. The paper is based on a questionnaire survey completed by 82 lecturers from a selected sample of public and private universities in Kenya. The results of analysis indicate that Vice Chancellors/Chief Executive Officer (CEO) characteristics, namely:keenness on modern information communication and technologies (ICTs), Influence on ICTs development, and, visionary ICT leadership are important determinants of LMS adoption and diffusion by instructors in higher education. Further, organizational variables of Subjective norm $(\mathrm{SN})$, availability of ICTs (AICT), Organizational support (OS), Organizational readiness (OR), and top management support (TMS) were related to behavioural intentions to use (BIU) LMS by academic staff for teaching and learning. In addition, in this paper, the technology acceptance model (TAM) was also extended to include $\mathrm{VCs} / \mathrm{CEO}$ characteristics, and organizational readiness. Results from the research also determined the factor that was dominant in predicting the acceptance of LMS which was top management support. This paper further validated the use of TAM, as a supportive framework for investigating the academic staff intentions to use Learning Management Systems for teaching and learning.
\end{abstract}

Keywords: Adoption, Diffusion, ICTs, CEO Characteristics, LMS, TAM, Internet, VC

\section{Introduction}

Learning Management Systems (LMS) are slowly being introduced in Kenyan Universities to improve learning and instruction as well as to gain competitive advantage (Wannemacher, 2006). Consequently, universities must face the challenge in having to get academic staff to adopt and make effective use of them in teaching and learning since technology rejection is common (Davis F. D., 1989; Davis, Bagozzi, \& Warshaw, 1989; Venkatesh \& Bala, 2008). Therefore there is a need for more successful mechanisms of increasing the adoption of LMS technologies by academic staff in universities since it is an ideal solution for improving access and the quality of teaching and learning (Yun \& Murad, 2006).This need is even more urgent for universities in a developing nation like Kenya where large scale deployment of LMS has not taken off in the past due to internet bandwidth cost and internet limitations (Gerhan \& Mutula, 2005). Now that the fibre cable is to connect Kenya with the rest of the world, a window of opportunity for Kenyan universities has opened for them to exploit these technologies to the full. However, one 
challenge is eminent, technology rejection by academic staff. The objective of exploratory research presented in this paper is to determine the extent to which Learning Management Systems (LMS) technologies will be employed in Kenyan Universities by academic staff for teaching and learning and to identify those factors that may act as barriers or catalyst to the adoption and diffusion of these technologies. The ubiquitous presence of ICTs in higher education institutions, especially the internet and its derivatives such as web-based learning management systems, and their potential impact on learning, teaching, and research, implies that any endeavour that would shed light on this technology is laudable. This underscores the need to for administrators and instructional leaders, in higher educational institutions to understand the causes and intensity of opposition and resistance by academic staff to using ICTs. In addition, there is a requirement to establish the underlying factors that impede or promote academic staff's response to the web-based Learning Management System (LMS) for instructional and course delivery in universities in Kenya as well as elsewhere on the planet.

\section{Literature Review}

Electronic learning is often abbreviated to e-learning. It can be defined as any learning activity supported by information and communication technologies - or ICTs (Sambrook, 2003 ). On the other hand Uys, Kiravu, and Mothibi (2004), define eLearning as the appropriate organization of ICTs for advancing student oriented, active, open, collaborative and life-long teaching-learning processes. This definition includes university-wide information systems that embrace blended learning so that students can profit from the appropriate mix of teaching and learning strategies to minimize the constraints that may be posed by distance and limited resources.

Thong and Yap (1995) empirically developed and tested an adoption model which highlighted the role of an organization's CEO characteristics as significant determinants of IS adoption. However, the adoption of e-learning into educational institutions of higher learning has been the latest trend. These technologies have been proven very much effective in the process of teaching and learning in other regions like Malaysia, consequently in recent years; the diffusion process of e-learning has been, at the centre of several recent studies (Ndubisi N. O., 2007). Nevertheless, these researches focused mainly on the USA case, where there has been an exponential adoption both in the public and private sectors (Yun \& Murad, 2006). Thus, from this perspective, this paper contributes to understand the diffusion process of e-learning in a specific country and sector and deals with the following question: Are there dominant factors in the organizational context that influence the rate and the model of adoption and diffusion of ICTs such as elearning systems in Kenyan higher education institutions? Building on bandwagon diffusion theories and institutional literature, the paper analyses the antecedents of the LMS adoption and diffusion process in higher education.

\section{Research Design}

The research design for the study on which this paper is based consisted of a survey seeking input from academic staff in Kenyan private and public universities. Although the survey considered a large number of issues, this paper focuses on the investigation on the factors that influence the diffusion and infusion of LMS by instructors in higher education institutions. These factors were grouped in four categories namely environmental, technological, organizational, and 
individual context factors, and adopted the technology acceptance model (TAM) based on (Davis F. D., 1989) and (Davis, Bagozzi, \& Warshaw, 1989). The focus for this paper is the organizational factors namely Subjective Norm (SN), Organizational ICT Support (OS), Availability of ICTs (ACT), VC/CEO characteristics (CEO), Organizational readiness (OR), and Top Management support (TMS). These were modelled in addition to the TAM variables Behavioural Intention to Use (BIU), Perceived Usefulness (PU), and Perceived Ease of Use (PEOU). The survey questions were structured to include the following broad constructs: environmental characteristics (Meso, Musa, \& Mbarika, 2005; Musa, 2006; Mathieson, Peacock, \& Chin, 2001), Technology characteristics (Davis F. D., 1989; Davis, Bagozzi, \& Warshaw, 1989; Venkatesh \& Bala, 2008), individual characteristics (Crump, Logan, \& McIlroy, 2007; Hashim, 2008; Ndubisi N. O., 2007; Ndubisi N. O., 2005; Lynn \& Halstead, 2003; Ankem, 2004; Roy \& Ghose, 2006) and organizational characteristics (Venkatesh \& Bala, 2008). Most items or variables in the survey were mapped to a seven point Likert scale. An overall average of responses to questions in each factor in a category was used to measure each construct. This paper presents the findings on the influence of organizational factors to individual academic staff members to adopt and diffuse LMS using the research model shown in Figure 1.

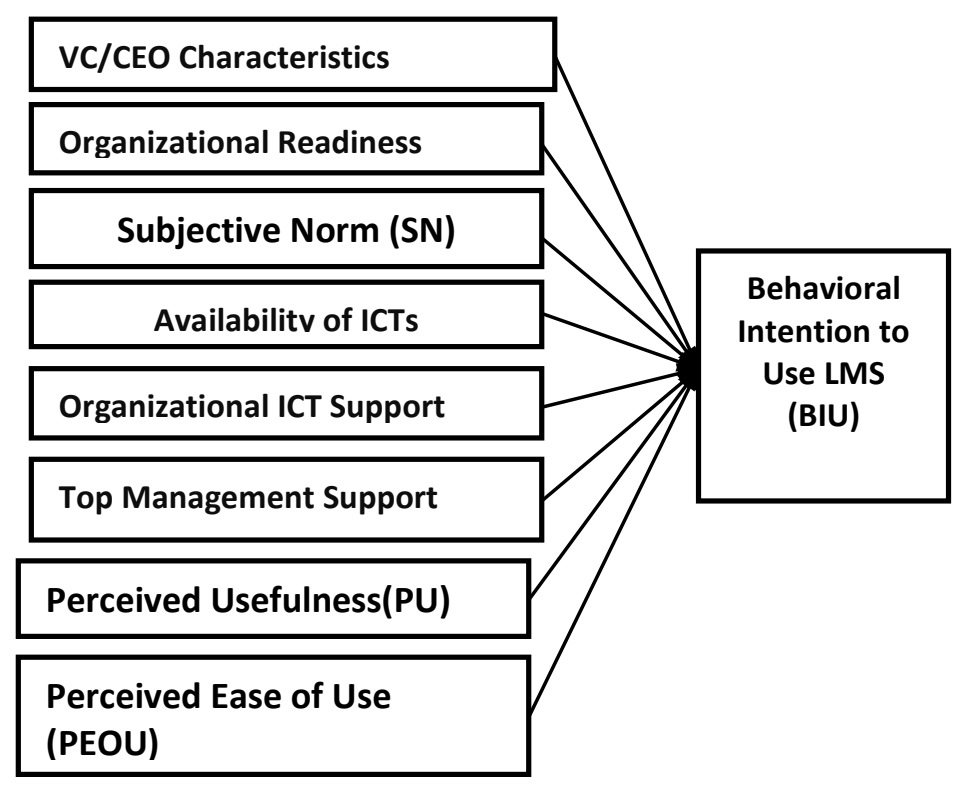

Figure 1: Research Model

Consequently, the following hypothesis was tested using Technology Acceptance Model (TAM):

H1: VC/CEO Characteristics have a positive influence on LMS adoption and diffusion by Academic staff;

H2: University readiness (OR) has a positive influence on LMS adoption and diffusion by Academic staff;

H3: Subjective Norm (SN) has a positive influence on LMS adoption and diffusion by Academic staff; 
H4: Availability of ICTs (AICT) has a positive influence on LMS adoption and diffusion by Academic staff;

H5: Organisational support (OS) has a positive influence on LMS adoption and diffusion by Academic staff;

H6: Top management (TMS) has positive influence on LMS adoption and diffusion by Academic staff;

H7: Perceived usefulness (PU) has positive influence on LMS adoption and diffusion by Academic staff; and

H8: Perceived ease of use (PEOU) has positive influence on LMS adoption and diffusion by Academic staff.

\section{Data Analysis and Results}

The 82 Lecturers from the participating universities in Kenya, completed a survey questionnaire which included construct items adapted from previous studies including (Davis F. D., 1989; Davis, Bagozzi, \& Warshaw, 1989; Davis F. D., 1993; Venkatesh \& Bala, 2008) instruments and some questions on demographics. The questionnaires returned comprised of $50 \%$ that were collected completed and useable statistical analysis. The demographic data shown in Table 1 revealed that the sample comprised of gender ( $23.2 \%$ female, $76.8 \%$ male $)$, and age $(14.6 \%<26$ yrs, $26.8 \%$ 26-35yrs, $41.5 \%$ 36-45 yrs, $17.1 \%>45 \mathrm{yrs}$ ). The sample also demonstrated that the number of instructors with doctorate degrees were equal to those with masters degree at $37 \%$. In order to test the hypotheses, the hypothesized linear relationships were modelled with a multiple regression model.

Table 1: Demographics of the sample

\begin{tabular}{|c|l|l|}
\hline Item & $\mathbf{N}$ & $\mathbf{\%}$ \\
\hline Gender & & \\
\hline Male & 63 & 76.8 \\
\hline Female & 19 & 23.2 \\
\hline Age Group & & \\
\hline Below 26 & 12 & 14.6 \\
\hline $26-35$ & 22 & 26.8 \\
\hline $36-45$ & 34 & 41.5 \\
\hline Over 45 & 14 & 17.1 \\
\hline Education Level & & \\
\hline Bachelor & 19 & 23.2 \\
\hline Masters & 31 & 37.8 \\
\hline Doctoral & 31 & 37.8 \\
\hline ICT Experience & & \\
\hline Poor & 2 & 2.4 \\
\hline Weak & 1 & 1.2 \\
\hline Below Avg. & 7 & 8.5 \\
\hline Average & 25 & 30.5 \\
\hline
\end{tabular}




\begin{tabular}{|c|l|l|}
\hline Above Avg. & 11 & 13.4 \\
\hline Good & 26 & 31.7 \\
\hline Excellent & 10 & 12.2 \\
\hline
\end{tabular}

The questionnaire items measuring instructor's perceptions relating to each of the eight ICT and LMS adoption variables were adapted from the previous studies. Following pilot surveys and discussions with the ICT instructors, some changes were recommended to the questionnaire by the instructors due to their repetitiveness and/or lack of relevance to LMS use in the universities teaching and learning contexts. The CEO and Organizational readiness constructs were added to the final measurement instrument, since the ICT instructors viewed these items as important factors in the study context. In summary, a total of eight multi-item scales were used to measure the independent variables in this study. Four single item measures asking instructors about their intended future use of the LMS were utilized to measure the dependent variables in this paper. All items were measured on a seven point Likert scale with polar anchors "Very strongly disagree" and "very strongly agree".

Mean scores were calculated from the summated responses to the items forming each independent variable. In this study Cronbach's alpha was used to assess the internal consistency reliability of each of the nine LMS diffusion variables. The results shown in Table 2 indicate that all variables displayed acceptable results for internal consistency reliability

Table 2: Measurements Reliability

\begin{tabular}{|cl|c|l|l|}
\hline Variables & N & $\begin{array}{l}\text { N of } \\
\text { Items }\end{array}$ & $\begin{array}{l}\text { Cronbach's } \\
\text { Alpha }\end{array}$ \\
\hline 1. & $\begin{array}{l}\text { PU-Perceived } \\
\text { Usefulness }\end{array}$ & 76 & 4 & 0.506 \\
\hline 2. & $\begin{array}{l}\text { PEOU-Perceived Ease } \\
\text { of Use }\end{array}$ & 76 & 5 & 0.911 \\
\hline 3. & $\begin{array}{l}\text { BIU- Behavioural } \\
\text { Intension to Use }\end{array}$ & 76 & 2 & 0.862 \\
\hline 4. & SN-Subjective Norm & 80 & 4 & 0.910 \\
\hline 5. & $\begin{array}{l}\text { AICT-Availability of } \\
\text { ICTs in the Organization }\end{array}$ & 81 & 4 & 0.855 \\
\hline 6. & $\begin{array}{l}\text { OS-Organizational } \\
\text { Support }\end{array}$ & 81 & 4 & 0.930 \\
\hline 7. & $\begin{array}{l}\text { CEO -VC's } \\
\text { Characteristics }\end{array}$ & 81 & 3 & 0.813 \\
\hline 8. & $\begin{array}{l}\text { OR-Organizational } \\
\text { Readiness- }\end{array}$ & 81 & 3 & 0.892 \\
\hline 9. & $\begin{array}{l}\text { TMS-Top Management } \\
\text { Support }\end{array}$ & 80 & 4 & 0.903 \\
\hline
\end{tabular}

On the other hand, Table 3 shows that top management support had the highest mean score. 
Table 3: Descriptive Statistics

\begin{tabular}{|l|c|c|c|c|c|}
\hline & & & & & $\begin{array}{c}\text { Std. } \\
\text { Deviati } \\
\text { on }\end{array}$ \\
\hline PU & 76 & 1.00 & 7.00 & 4.9178 & 1.52063 \\
PEOU & 76 & 1.00 & 7.00 & 4.6645 & 1.46887 \\
BIU & 79 & 1.00 & 7.00 & 5.4114 & 1.38619 \\
SN & 80 & 1.00 & 7.00 & 5.0625 & 1.44438 \\
AICT & 81 & 1.75 & 7.00 & 4.9290 & 1.44278 \\
OS & 77 & 1.00 & 7.00 & 4.8539 & 1.59479 \\
CEO & 82 & 2.00 & 7.00 & 5.4187 & 1.25905 \\
OR & 81 & 1.00 & 7.00 & 5.4486 & 1.25295 \\
TMS & 80 & 1.00 & 7.00 & 5.5969 & 1.11980 \\
Valid & & & & & \\
N & 63 & & & & \\
(listwise & & & & & \\
) & & & & & \\
\hline
\end{tabular}

To establish the construct validity of the instrument used in this study factor analyses were performed using the principal components method of analysis. The results had loading onto eight distinct factors. All loadings were in the acceptable $(>0.5)$ to excellent range $>0.9)$ providing further support for the instrument used in this study. A multiple regression analysis was conducted of all eight LMS adoption variables on the dependent variable intention to use LMS for teaching and learning. The results indicate strong support for hypothesis 1 (see table 4).

\section{Table 4: Full Model Regression}

\begin{tabular}{|l|r|r|r|r|r|}
\hline Model & $\begin{array}{c}\text { Sum of } \\
\text { Square } \\
\text { s }\end{array}$ & df & $\begin{array}{c}\text { Mean } \\
\text { Square }\end{array}$ & F & Sig. \\
\hline Regression & 35.063 & 8 & 4.383 & 4.074 & $.001(\mathrm{a})$ \\
Residual & 64.554 & 60 & 1.076 & & \\
Total & 99.617 & 68 & & & \\
\hline
\end{tabular}

a Predictors: (Constant), TMS, PU, AICT, OS, PEOU, SN, OR, CEO

b Dependent Variable: BIU

The full model regression equation was statistically significant $(\mathrm{p}<.001)$ and explained approximately $35 \%$ of the variation in BIU $(\mathrm{R}=.352)$. Model reduction techniques were then used to formulate a reduced model including only the significant variables of Subjective norm, availability of ICTs, Organizational support, CEO characteristics, Organizational readiness, and top management support. 
The results shown in Table 5 indicate that the reduced model regression equation was statistically significant $(\mathrm{p}<.0001)$ and there was no significant difference between the full and reduced model in terms of their ability to explain variation in BIU $\left(\mathrm{R}^{2}=.34 .704\right)$.

Table 5: Reduced Model Regression

\begin{tabular}{|l|r|r|c|c|c|}
\hline & \multicolumn{1}{|c|}{$\begin{array}{c}\text { Mean of } \\
\text { Model }\end{array}$} & \multicolumn{1}{|c|}{$\begin{array}{c}\text { Squar } \\
\text { Squares }\end{array}$} & df & F & Sig. \\
\hline Regression & 34.704 & 6 & 5.784 & 5.630 & $.000(\mathrm{a})$ \\
Residual & 68.827 & 67 & 1.027 & & \\
Total & 103.530 & 73 & & & \\
\hline
\end{tabular}

a Predictors: (Constant), TMS, AICT, SN, OS, OR, CEO

b Dependent Variable: BIU

The results also indicate that Subjective norm, availability of ICTs, Organizational support, CEO characteristics, Organizational readiness, and top management support have a positive and significant relationship with BIU. Similarly, Pearson correlation analysis was conducted to examine all the bivariate relationships among the factors as depicted in Table 6.

\section{Table 6: Pearson Correlations}

\begin{tabular}{|l|l|}
\hline ITEM & BIU \\
\hline BIU & 1 \\
\hline PU & $.236\left(^{*}\right)$ \\
\hline EOU & .161 \\
\hline SN & $.245\left(^{*}\right)$ \\
\hline ACT & .194 \\
\hline OS & $.382\left(^{* *}\right)$ \\
\hline CEO & $.290\left(^{*}\right)$ \\
\hline OR & $.247\left(^{*}\right)$ \\
\hline TMS & $.494\left(^{*}\right)$ \\
\hline
\end{tabular}

Statistical results show that significant correlations exist between behavioural intentions towards learning management systems adoption with Subjective norm, availability of ICTs, Organizational support, CEO characteristics, Organizational readiness, and top management support. The independent variable, BIU has a highest positive correlation with top management support variable at .494 .

Meanwhile, Table 7 shows the results of regression analysis that was conducted between variables. There is evidence of a significant relationship between the independent variables and the behavioural intention towards learning management systems adoption. The F value of 4.074 is significant at $\mathrm{p}<.005$, indicating that there exists at least one significant predictor. $\mathrm{R}^{2}$ value of .352 indicates that about $35 \%$ of the variance in LMS adoption can be explained by the independent variables. 
Table 7: Regression Coefficients

\begin{tabular}{|l|r|r|r|}
\hline & \multicolumn{1}{c|}{ B } & \multicolumn{1}{c|}{$\mathrm{t}$} & \multicolumn{1}{c|}{ sig } \\
\hline (Constant) & 2.505 & 3.534 & .001 \\
\hline PU & .139 & 1.143 & .258 \\
\hline PEOU & -.131 & -1.102 & .275 \\
\hline SN & -.144 & -1.228 & .224 \\
\hline AVICT & .168 & 1.344 & .184 \\
\hline OS & .247 & 1.936 & .058 \\
\hline CEO & -.155 & -.853 & .397 \\
\hline OR & -.165 & -1.048 & .299 \\
\hline TMS & .590 & 3.445 & .001 \\
\hline F value & 4.074 & & \\
\hline Sig. F & 0.001 & & \\
\hline R $^{2}$ & 0.352 & & \\
\hline $\begin{array}{l}\text { Durbin- } \\
\text { Watson }\end{array}$ & 1.880 & & \\
\hline
\end{tabular}

a Dependent Variable: BIU

\section{Discussion and Conclusion}

The goal of this paper was to provide more insight in the adoption and diffusion of learning management systems by university academic staff and the role of the university vice chancellors ( $\mathrm{VC} / \mathrm{CEO}$ ), in addition to the other universities' factors in the LMS adoption process, which so far has received very little attention in the ICT diffusion literature. The outcomes of the multivariate analyses indicate that while controlling for characteristics of the universities, the Vice Chancellor characteristics such as keenness on modern ICTs, Influence on ICTs development, and, visionary ICT leadership matter for the adoption and diffusion of learning management systems by academic staff. Further, the results show that organizational readiness plays a key role in LMS diffusion. Consequently, future empirical research should take this into account when assessing the factors that determine LMS adoption by instructors in higher education. Table 8 summarizes the finding of this paper. 
Table 8: Results of the hypothesis testing

\begin{tabular}{|l|l|l|}
\hline H & Description & $\begin{array}{l}\text { Supp } \\
\text { ort }\end{array}$ \\
\hline H1 & $\begin{array}{l}\text { VC/CEO Characteristics have a } \\
\text { positive influence on LMS adoption } \\
\text { and diffusion by Academic staff }\end{array}$ & Yes \\
\hline H2 & $\begin{array}{l}\text { University readiness has a positive } \\
\text { influence on LMS adoption and } \\
\text { diffusion by Academic staff }\end{array}$ & Yes \\
\hline H3 & $\begin{array}{l}\text { Subjective Norm has a positive } \\
\text { influence on LMS adoption and } \\
\text { diffusion by Academic staff }\end{array}$ & Yes \\
\hline H4 & $\begin{array}{l}\text { Availability of ICTs have a } \\
\text { positive influence on LMS adoption } \\
\text { and diffusion by Academic staff }\end{array}$ & No \\
\hline H5 & $\begin{array}{l}\text { Organisational support has a } \\
\text { positive influence on LMS adoption } \\
\text { and diffusion by Academic staff }\end{array}$ & Yes \\
\hline H6 & $\begin{array}{l}\text { Top management has positive } \\
\text { influence on LMS adoption and } \\
\text { diffusion by Academic staff }\end{array}$ & $\begin{array}{l}\text { Yes } \\
\text { influence on LMS adoption and } \\
\text { diffusion by Academic staff }\end{array}$ \\
\hline H8 & $\begin{array}{l}\text { Perceived ease of use has positive } \\
\text { influence on LMS adoption and }\end{array}$ & No \\
\hline
\end{tabular}

The findings of this paper agree with those of (Ani, Esin, \& Edem, 2005) who found an association between vice chancellors attitude towards ICTs, and ICT adoption in their respective libraries. Ani et Al., (2005) further suggested that national wide seminars and workshops for all vice chancellors to address their attitude on ICTs to make them give way to positive ones that enhance rapid adoption of ICT in their university libraries. From the results of this paper, we can therefore generalize that Vice chancellors characteristic related to ICTs influence academic staff to adopt and diffuse LMS in their teaching and learning.

\section{Recommendations For Future Directions}

Based on the results of the study, the following recommendations will be of contributory values to the Vice chancellors and university councils, information systems (IS) field, higher education sector, Ministry of higher education, ICT development partners in higher education, and LMS software vendors. This study found that VC's characteristics are crucial to LMS adoption by academic staff. This implies that for universities to have a success in LMS implementation, adoption and diffusion by instructors, the VC's must not only have a clear ICT vision, but also offer ICT leadership, and be keen to equip their universities with modern ICT facilities.

Vendors have to ensure that before they sell an LMS, they have created the right organizational environment, where the $\mathrm{VC}$ is the project champion with a clear vision and offers project leadership. The academic staff will need modern equipment. However it is noted from the result 
of this paper that the availability of ICT equipment even if it is perceived to be easy to use has little influence on academic staff uptake of LMS. This implies that the factors of subjective norm, organizational support, and top management support in addition to organizational readiness and CEO characteristics are more critical in LMS adoption and diffusion.

\section{References}

Ani, O. E., Esin, J. E., \& Edem, N. (2005). Adoption of information and communication technology (ICT) in academic libraries. The Electronic Library, 23 (6), 701-708.

Ankem, K. (2004). Adoption of Internet resource-based value-added processes by faculty in LIS education. Library and Information Science Research , 26 (4), 482-500.

Crump, B. J., Logan, K. A., \& McIlroy, A. (2007). Does Gender Still Matter? A Studyof the Views of Women in the ICT Industry in New Zealand. Gender, Work and Organization , 14 (4), 249-370.

Davis, F. D. (1989). Perceived Usefulness, Perceived Ease of Use, and User Acceptance of Information Technology. MIS Quarterly, 13 (3), 318-339.

Davis, F. D. (1993). User Acceptance of Information Technology: System Characteristics, User Perceptions and Behavioral Impacts. International Journal of Man-Machine Studies , 38, 475487.

Davis, F. D., Bagozzi, R. P., \& Warshaw, P. R. (1989). User acceptance of computer technology: A comparison of two theoretical models. Management Science , 35, 982-1003.

Gerhan, D. R., \& Mutula, S. M. (2005). Bandwidth bottlenecks at the University of Botswana. Library Hi Tech , 23 (1), 102-117.

Hashim, J. (2008). Gender in Management: An International Journal. Learning barriers in adopting ICT among selected working women in Malaysia , 23 (5), 317-336.

Lynn, M., \& Halstead, A. (2003). Knowledge and learning in female team managed firms adopting information comminication Technologies (ICTs). women in management review , 13 (6), 334-337.

Mathieson, K., Peacock, E., \& Chin, W. (2001). Extending the technology acceptance model:The influence of perceived user resources. Database for Advances in Information Systems , 32 (3), 86.

Meso, P., Musa, P., \& Mbarika, V. (2005). Towards a model of consumer use of mobile information and communication technology in LDCs: the case of sub-Saharan Africa. Info Systems J , 15, 119-146. 
Musa, P. F. (2006). Making a Case for Modifying the Technology Acceptance Model to Account for Limited Accessibility in Developing Countries. Information Technology for Development , 12 (3), 213-224.

Ndubisi, N. O. (2005). Factors influencing e-learning adoption intention: Examining the determinant structure of the decomposed theory of planned behaviour constructs. Retreived from http://www.herdsa.org.au/wp-content/uploads/conference/2004/PDF/P057-jt.pdf , 252-262.

Ndubisi, N. O. (2007). Evaluating the direct and indirect impact of traits and perceptions on technology adoption by women entrepreneurs in Malaysia. Academy of Entrepreneurship Journal , 13 (2), 1-20.

Roy, S., \& Ghose, S. (2006). Converting internet non-users to internet users and to online buyers. University of New Haven;University of Wisconsin, Milwaukee.

Sambrook, S. ( 2003 ). E-learning in small organisations. Education and Training , 45 (8/9), 506516.

Uys, P., Kiravu, C., \& Mothibi, J. (2004). Case study: Implementing the LASO model: development of a pilot online course at the Faculty of Engineering and Technology, University of Botswana. Campus-Wide Information Systems. , 21 (4), 125-131.

Venkatesh, V., \& Bala, H. (2008). Technology Acceptance Model 3 and a Research Agenda on Interventions. Decision Sciences , 39 (2), 273-315.

Wannemacher, K. (2006). Functional Differentiation of Incentives for E-teaching at Universities. Current Developments in Technology-Assisted Education (2006) (pp. 72-76). London: FORMATEX.

Yun, G. P., \& Murad, M. W. (2006). Factors Influencing Psychology and Skills of the Secondary School Teachers' E-Learning Readiness: A Case Study in Malacca, Malaysia. Current Developments in Technology-Assisted Education , 7 (4), 2135-2140. 